\title{
ORGANIZATIONAL AND TECHNICAL ASPECTS OF INTRODUCTION OF INNOVATIONS OF ORGANIC AGRICULTURE AND RATIONAL LAND USE OF THE AGRARIAN ENTERPRISES
}

\section{Yulia Demydenko ${ }^{1}$ \\ Liudmyla Makeienko ${ }^{2}$}

\section{DOI: https://doi.org/10.30525/978-9934-588-11-2_5}

The innovative nature of production should be supported by attracting a healthy level of investment. Agro-industrial sector is one of the leading sectors in the economy of Ukraine in terms of capital investments. On the one hand, relative stagnation, stability of the domestic economy, on the other, pent-up demand for investments in the tough time in 2014-2015. These factors influenced a dynamic improvement in attracting investment in the sector in recent years [1, p. 44-48].

For example, according to the Office for National Statistics, the amount of capital investments in agriculture increased by almost $28 \%-634$ billion UAH in 2017 , compared to 2016.

Positive trend continued in the previous year. According to official statistics, in the period from January to June 2018, agro-industry acquired 264 billion UAH that is $9 \%$ more than in the same period of the previous year. Only the innovative development of the agricultural sector can influence further investment flows to Ukraine (Official site of the State Statistics Service of Ukraine, 2018 [5, p. 175].

In addition, the development of organic farming, the process of reviving the fertility of agricultural lands, may solve many problems associated with the renewal of the Ukrainian village. The works of domestic and foreign scientists show a great interest in this subject and are the basis for further investigation.

Using Agrovit-Kor fertilizer that we offer for Ukrainian soilsis the latest development which aims to increase the soil fertility and introduce science-based farming. There is no data found about using complex organic fertilizer (COF) in the fields of Eurasia, however, it is obvious that this issue is under investigated and requires additional studies and further research [4, p. 86-96].

The purpose of the article is to investigate the implementation of innovations, scientific and technological development progress in the agro-industrial sector of Ukraine, considering the international practices.

Construction of enterprises for growing and processing poultry is aligned with an increased demand for chicken in both domestic and foreign markets. Due to lower cost, compared to other types of meat, the share of poultry in the structure of meat consumption in Ukraine is gradually growing and today is $49 \%$, while the share of pork is $40 \%$ and beef $-11 \%$. In addition, domestic companies continue to increase exports of poultry meat. In particular, in January-September 2018, Ukraine shipped

\footnotetext{
${ }^{1}$ Sumy National Agrarian University, Ukraine

${ }^{2}$ Sumy National Agrarian University, Ukraine 
215 thousand tons of poultry meat abroad, which is $11.9 \%$ more than in the same period of the previous year [2, p. 428].

Considering the fact that the Saudi investment fund SALIC has recentlypurchased the agricultural holding Mriya and the President of Ukraine stated that our country is ready to create all the necessary conditions to attract investors, experts and market participants still believe that these events will not be a crucial drive or a strong positive signal for attracting investment in domestic agricultural sector [3, p. 59-63].

The companies from the Sumy Region were selected based on published data of financial organizations, government and companies themselves. All they should have already implemented projects, funded and launched in 2015-2018.

Options 2 and 3 are relevant for innovation activity of Kernel company: Kernel agricultural enterprise cultivate land in the Sumy Region - in Nedryhailivskyi, Romenskyi, Burynskyi, Trostianetskyi, Velyka Pysarivka, Krasnopilskyi, Bilopilskyi, Lypova Dolyna, Sums'kyi, Lebedynsky districts. Therefore, the production and use of innovative fertilizer is the latest development, which aims to increase soil fertility and maintain science-based farming.

Kernel is the world's leading and the largest in Ukraine producer and exporter of sunflower, a key supplier of agricultural products to world markets from the Sumy region, and is part of the Druzhba Nova cluster. Kernel company exports its products to more than 60 countries around the world. It also aims to double export volumes in the financial year 2016-2020 through balanced development of agricultural production with low cost due to investments in technology.

The increase in the production of sunflower in Ukraine is stimulated by the owners of processing enterprises who are trying to load their plants as much as possible. By the way, the export of oil and fat products in the structure of the agricultural production is $28 \%$.

The problem today is not that sunflower occupies $20-25 \%$ of the cultivated area, but ignoring the necessary measures to balance its impact on the soil and other crops. And if balance of nutrients and moisture is not taken into account, then even limitations of 7-8 years on re-seeding will not change the situation.

New fertilizer allows not to change the soil in greenhouses up to five years. A distinctive feature of $\mathrm{COF}$ from other types of fertilizers is a high concentration of nutrients (nitrogen, phosphorus, potassium, organic matter), environmental safety (no heavy metals, pesticides), low amounts (biohumus - from 3.0 to 10 tons per hectare, super-fertilizer - from 0.5 to 2.0 tons per hectare for cereals and up to 3.0 tons per hectare - for potatoes).

For intrafarm usage of concentrated organic fertilizers, which should be carried out simultaneously with the row-crop planting, a machine based on the seed drill SUPH-8 was developed. It allows to apply concentrated organic fertilizers in amount from 0.4 to $3.6 \mathrm{t} / \mathrm{ha}$. The developed power-driven process showed positive results during production inspection and testing at the machine-tractor station. These results allowed to start the serial production of necessary devices. So, the innovative nature of COF super fertilizer Agrovit-Kor is supported by positive aspects in ecology, economics, and the efficiency of agricultural production. The capacity of COF production line 
may differ. Preliminary calculations have shown that of all possible alternatives, an average agricultural enterprise will be satisfied with a line with a capacity of up to 3 tons per day. But theoretically, the volume of COF production can be 100 tons per year.

It is planned to engage ZAT Nadiya, a private company (Sumy Region, Lebedyn, 30 Lenina Street), which deals with raising beef cattle, to the production of manure. In accordance with the established composition of COF components, we determined the required number of components, taking into account the farm demand for the 10th crop rotation, the farm field size -1257 hectares and the rate of fertilizer usage for one field of crop rotation -0.75 tons/ha.

The farm has the necessary amount of the most significant component in the structure - decomposed manure. The soil, which is a part of the fertilizer, is taken from any field. It does not have to be chernozem (black-earth soil), but not the clay. The rest of the components the farm must purchase.

The issue of preserving the soil fertility under agrarian production in modern conditions of management remains relevant. Thus, in the Sumy region, the annual loss of humus in agricultural land is very high - more than 1.1 tons per hectare. Soil fertility is a variable quality of land, which is determined by the content of humus. As a result of the continuous exploitation of arable land, a large amount of nutrients and humus is produced by the harvest, but these stocks are not replenished entirely because of the very limited amount of fertilizers, in particular organic ones. Reduced humus content in the soil is accompanied by a decrease in crop production, a decrease or lack of profits of agrarian enterprises.

The proposed model will create a sustainable base for the development of an agricultural enterprise of the «science-development-introduction-competitivenessprofit» type.

In order to ensure the success of COF production by ZAT Nadiya in Sumy Region it is necessary to: effectively use all available resources of the farm; increase staff productivity; optimize production processes, reduce the cost of working time; minimize risks; enter the domestic market with innovative products COF and forecast export operations.

Hence, it should be noted that soil fertility of the agricultural land is an important object of state protection. The biggest natural wealth of Ukraine is black soil (chernozemic soil). It occupies almost 50\% of the world's black soil reserves. Plowed land in Ukraine makes up about $85 \%$ of the area of steppes (campo ucn.) and foreststeppes. The cultivated area occupies 33,5 million ha. $60 \%$ of black soil has already been damaged, 100 thousand hectares of fertile soils are lost every year. Therefore, preserving our national wealth - land resources, is possible only through introducing organic farming and rational land use, taking into account its capabilities.

\section{References:}

1. Vinichenko, I. I. (2012). Innovatsiyna diyal'nist' ahrarnykh pidpryyemstv: derzhavna ta priorytetna [Innovative activity of agrarian enterprises: state and priority]. Bulletin of the International Nobel Economic Forum. Vol. 1 (5). P. 44-48. 
2. Datsij, O. I. (2004). Rozvytok innovatsiynoyi diyal'nosti v ahropromyslovomu vyrobnytstvi Ukrayiny [Development of innovative activity in agroindustrial production of Ukraine]. NNTs IAE, Kyiv.

3. Zubariev, A. S., Yemelianov, S. H., \& Borysohlibskyi, L. N. (2010). Stvorennya rehional'noyi innovatsiynoyi systemy ye pokaznykom stiykoho rozvytku ekonomiky rehionu [The creation of a regional innovation system is an indicator of the sustainable development of the region's economy]. Economy and the state. Vol. 7. P. 59-63.

4. Matrosova, V. O. (2013). Suchasni teoretychni ta metodychni pidkhody do otsinky efektyvnosti vykorystannya innovatsiynoho potentsialu pidpryyemstva [Modern theoretical and methodical approaches to assessing the effectiveness of using innovative potential of the enterprise]. Visnyk NTU «KhPI». Vol. 66 (1036). P. 86-96.

5. Tolbatov, A. V. (2018). Naukove seredovyshche suchasnoyi lyudyny: ekonomika, menedzhment, medytsyna ta farmatsevtyka, khimiya, biolohiya, sil's'ke hospodarstvo, heohrafiya ta heolohiya. [The scientific environment of modern man: Economics, Management, Medicine and Pharmaceuticals, Chemistry, Biology, Agriculture, Geography and Geology: monograph]. Odessa.

\section{ADAPTIVE PROPERTIES OF MAIZE FORMS FOR IMPROVEMENT IN THE ECOLOGICAL STATUS OF FIELDS}

\section{Artem Maksymenko ${ }^{1}$ Kristina Tsigelnik ${ }^{2}$}

DOI: https://doi.org/10.30525/978-9934-588-11-2_6

Maize is a dominant crop in the world's total grain production. Approximately 850 million tons of maize, with an average yield of $5.2 \mathrm{t} / \mathrm{ha}$, are produced on the total area of 162 million hectares. In more recent times, the production of this crop grain has increased at a record pace up to 850 million tons in the world, and 39.0$46.2 \%$ of it is harvested in the United States, the high gross yield is observed in China and Brazil as well.

In Ukraine, 4.5-5.0 million hectares are occupied by maize that is almost a quarter of all grain crops. Grain maize is grown on 4.0-4.5 million hectares, maize for silage and green fodder - on 0.2-0.4 million hectares [1, p. 783-790; 3, p. 40-45]. The introduction of intensive technology and new high-performance hybrids into production has significantly increased the yield of maize on large areas. Many of the best farms obtain 9-10 t/ha or more, including in new maize-growing areas (Polissia of Ukraine). In some regions of Ukraine, the yield is amounted to 4.5-6.0 t/ha, but in general in Ukraine the volume of maize yield remains low, including as a consequence of entomopathogens and phytopathogens [1, p. 783-790].

According to the long-term data, the total shortfall in maize grain production caused by stem rot, smut, kernel rot and European com borer is estimated at an average of $30.9 \%$.

\footnotetext{
${ }^{1}$ Sumy National Agrarian University, Ukraine

${ }^{2}$ Sumy National Agrarian University, Ukraine
} 